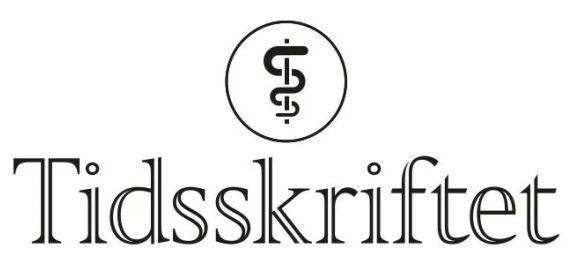

DEN NORSKE LEGEFORENING

\title{
Behandling av alvorlige brannskader
}

\author{
OVERSIKTSARTIKKEL
}

\section{ANNE BERIT GUTTORMSEN}

Email:anne.guttormsen@helse-bergen.no

\section{HENNING ONARHEIM}

Kirurgisk serviceklinikk

Haukeland universitetssykehus

5021 Bergen

og

Institutt for kirurgiske fag

Universitetet i Bergen

\section{JON THORSEN}

Kirurgisk serviceklinikk

SVEIN ARTHUR JENSEN

\section{BJ ØRN ERIK ROSENBERG}

Plastikkirurgisk avdeling

Kirurgisk klinikk

Haukeland universitetssykehus

\section{BAKGRUNN.}

Brannskadebehandling er utfordrende både kirurgisk og intensivmedisinsk.

MATERIALE OG METODE.

Artikkelen er basert på egne erfaringer og et ikke-systematisk litteratursøk i PubMed.

\section{RESULTATER.}

Ved brannskader som omfatter $>10-15 \%$ av kroppsoverflaten bør væskeresuscitering startes tidlig. Væske bidrar til ødemdanning, og brannskade i ansiktet kan nødvendiggjøre tidlig intubasjon for å sikre frie luftveier. Ved kompromittert sirkulasjon eller respirasjon forårsaket av dyp brannskade må eskarotomi og fasciotomi gjennomføres ved lokalsykehuset. Respirasjonssvikt kan skyldes overvæsking, sekretstagnasjon, pneumoni og/eller sepsis. Fiberbronkoskopi dokumenterer inhalasjonsskade og gir mulighet for fjerning av sekret fra luftveiene. I akuttfasen skyldes hypotensjon vanligvis hypovolemi. Senere i forløpet vil en massiv inflammatorisk respons (systemisk inflammatorisk respons- 
syndrom, SIRS) ofte gi vasodilatasjon ledsaget av hypotensjon og økt hjerteminuttvolum. Infeksjoner i sår og luftveier er vanlig. Vi anbefaler ikke profylaktisk antibiotika. Systemisk inflammatorisk respons-syndrom kan gi tresifret CRP-nivå og en kroppstemperatur på 38 $39^{\circ} \mathrm{C}$. Dette gjør det vanskelig å finne korrekt tidspunkt for oppstart av antibiotikabehandling. Definitiv kirurgi (eksisjon og transplantasjon) bør tilstrebes så snart skadens dybde er kartlagt, helst innen en uke etter at skaden inntraff.

\section{FORTOLKNING}

Pasienter med store brannskader behandles etter generelle intensivmedisinske prinsipper, fortrinnsvis i avdelinger med erfaring med de spesielle problemstillingene hos denne pasientgruppen.

En brannskade er en termisk, kjemisk og/eller elektrisk skade av hud og/eller annet vev.

I Norge behandles ca. 700 pasienter per år i sykehus pga. brannskade. Om lag 10 \% av disse behandles ved Brannskadeavsnittet ved Haukeland universitetssykehus $(\underline{1}, \underline{2})$. Brannskadebehandling er en tverrfaglig oppgave, og i behandlingsteamet inngår plastikkirurg, anestesilege, intensivsykepleiere og fysioterapeut. Omfattende brannskader (tab 1) (3) krever engasjement, høyspesialisert intensivbehandling og en aggressiv tilnærming til kirurgisk intervensjon for å øke overlevelsen og oppnå et godt funksjonelt og kosmetisk akseptabelt behandlingsresultat.

\section{Tabell 1}

Brannskader - alvorlighetsgrad (3)

\begin{tabular}{|llccc|}
\hline Klassifisering & & Mindre skade & Moderat skade & Alvorlig skade \\
\hline Barn & Delhudsskade (\%) & $<10^{1}$ & $10-15$ & $>15$ \\
\hline & Fullhudsskade (\%) & $<2$ & $2-10$ & $>10$ \\
\hline Voksne & Delhudsskade (\%) & $<15$ & $15-30$ & $>30$ \\
\hline & Fullhudsskade (\%) & $<2$ & $2-10$ & $>10$ \\
\hline$[\mathrm{i}]$ & & & & \\
\hline
\end{tabular}

[i] ${ }^{1}$ Skadet areal angitt i prosent av kroppsoverflate

\section{Materiale og metode}

Grunnlaget for denne oversikten er forfatternes kliniske erfaring med behandling av store brannskader samt artikler funnet etter ikke-systematisk litteratursøk i PubMed og utvalgt ut fra vår erfaring med denne pasientgruppen.

\section{Patofysiologi}

I brannskadet hud er det økt kapillær lekkasje og $ø$ kt transkapillært filtrasjonstrykk («sug» i vevet) (4)-(ㅁ). Dette fører til at vann, salter og plasmaproteiner lekker til interstitiet og gir et raskt innsettende $ø \mathrm{dem}$. Omfatter skaden $>25 \%$ av kroppsoverflaten, vil det i tillegg til lokal ødemdanning være generalisert lekkasje av proteinholdig væske fra blodbanen til interstitiet. Dette fører til ødemer også i uskadet hud, muskulatur og indre organer (7.). 
Større brannskader fører til en uttalt stressrespons, som starter umiddelbart og kan vedvare i flere måneder. Pasientene er hyperdynamiske - med forhøyet kroppstemperatur, $\emptyset \mathrm{kt}$ oksygenforbruk og $\varnothing \mathrm{kt} \mathrm{CO}_{2}$-produksjon. Det er også et $\emptyset \mathrm{kt}$ forbruk av glukose, $\varnothing \mathrm{kt}$ glykogenolyse, proteolyse og lipolyse, samtidig som det er en uttalt insulinresistens med forhøyet blodsukkernivå ( $\underline{8})$.

\section{Inhalasjonsskade: karbonmonoksid- og cyanidforgiftning}

En inhalasjonsskade er forandringer i luftveier og lunger etter inhalasjon av røyk (partikler), gasser og opphetet luft/damp. Diagnosen stilles på grunnlag av sykehistorie (brann i lukket rom, tap av bevissthet) og kliniske funn med ansiktsbrannskade, svidde nesehår, sot i nese, munn eller svelg, sotfarget oppspytt, heshet, stridor og hvesende respirasjon. Den kan bekreftes med bronkoskopi, hvor man kan finne erytem, ødem, sot, sårdanning, økt sekretmengde og i alvorlige tilfeller nekrose med hvite områder i slimhinnen.

Ved nedsatt bevissthet og ved informasjon om brannrøyk i lukket rom må karbonmonoksidforgiftning (CO-forgiftning) mistenkes. Det synes ikke å være noen god korrelasjon mellom CO-Hb og alvorlighetsgrad av CO-forgiftningen (9.). Mistenkt COforgiftning behandles med $100 \%$ oksygen for å redusere halveringstiden for CO-Hb. Nytten av hyperbar oksygen (HBO) i behandlingen av CO-forgiftning er omdiskutert (9.)-(모). En stor randomisert klinisk studie viste at behandling med hyperbar oksygen sammenliknet med $100 \%$ oksygen ga mindre cerebrale bivirkninger (프), mens en Cochrane-gjennomgang konkluderer med at HBO-behandling ikke kan anbefales på bakgrunn av tilgjengelige studier (11). Ved Haukeland universitetssykehus behandles bevisstløse pasienter med antatt CO-forgiftning og gravide med $\mathrm{CO}-\mathrm{Hb}>20 \% \mathrm{i}$ trykkammer.

Ved brann i lukket rom må også cyanidforgiftning mistenkes, spesielt hvis pasienten har alvorlig metabolsk acidose og forhøyet serum-laktat uten samtidig forhøyet CO-Hb eller hypovolemi (13). Gjennomføring av prospektive randomiserte studier for å undersøke effekten av ulike antidoter forutsetter en rask metode for påvisning av cyanid. En slik metode er ikke er tilgjengelig i dag (13). Hydroksykobalamin, Cyanokit, $5 \mathrm{~g}$ intravenøst (voksendose) anbefales derfor på empirisk grunnlag som antidot ved mistenkt cyanidforgiftning. Cyanokit gir rødlig misfarging av huden og lillafarget urin $(13,14)$.

\section{Elektriske skader}

Høyvoltskader er termiske skader i vev forårsaket av elektrisk ledende materiale med spenning over 1 ooo V. Hud leder strøm dårligere enn muskulatur og underliggende bløtvev. De åpenbart synlige skadene etter slike ulykker kan derfor ofte være begrenset til kontaktpunktene for elektrodene i inngangs- og utgangssåret samt hudaffeksjon ved eventuell samtidig lysbue og brann i klær. Skadene i muskulaturen er ofte store og kan resultere i forhøyede blodverdier av myoglobin, med potensielt påfølgende fare for akutt nyresvikt. Traumet kan også påvirke hjertets ledningssystem, og - avhengig av alvorlighetsgrad - bør pasientene overvåkes med kontinuerlig EKG (15) i minst 24 timer etter skaden. Alvorlige brannskader kan også oppstå etter kontakt med elektriske anlegg med lav spenning, men høy strømføring (industrianlegg).

\section{Skadedybde}

Brannskader inndeles i overflatiske skader (epidermal, 1. grad), delhudsskader (dermal, 2. grad) og fullhudsskader (trans-/subdermal, 3. grad) (tab 2). Overflatisk skade, 1.-gradsskade, inkluderes ikke ved beregning av brannskadet areal uttrykt som prosentandel av kroppsoverflaten. 


\section{Tabell 2}

Klinisk vurdering av skadedybde

\begin{tabular}{|c|c|c|c|c|c|c|}
\hline \multicolumn{6}{|c|}{ Overflate } & \multirow[b]{2}{*}{ Smerte } \\
\hline $\begin{array}{l}\text { Dybde }^{1} \\
\text { (grad) }\end{array}$ & Fuktig/tø & mI & dem & irkulasjon & Farge & \\
\hline $\begin{array}{l}\text { Epidermal } \\
\text { (I) }\end{array}$ & Tørr & - & $+/-$ & Normal & Rød & ++ \\
\hline $\begin{array}{l}\text { Overfladisk } \\
\text { dermal } \\
\text { (delhud) } \\
\text { (Ila) }\end{array}$ & Fuktig & + & + & Normal & Rød & +++ \\
\hline $\begin{array}{l}\text { Dyp dermal } \\
\text { (delhud) } \\
\text { (IIb) }\end{array}$ & Fuktig & + & + & Nedsatt & Hvitaktig/perlehvit/voksaktig & $-/(+)$ \\
\hline $\begin{array}{l}\text { Subdermal } \\
\text { (fullhud) } \\
\text { (III) }\end{array}$ & Tørr & - & + & Ingen & Hvit/læraktig & $-/(+)$ \\
\hline [i] & & & & & & \\
\hline
\end{tabular}

[i] ${ }^{1}$ Ved delhudsskade endrer skadedybden seg de første par dagene

\section{Skadeutbredelse - «nierregelen»}

Skadeutbredelsen kan lettest estimeres ved at kroppsoverflaten deles opp i sektorer på $9 \%$ én overekstremitet $9 \%$, én underekstremitet $18 \%$, truncus forflate $18 \%$, truncus bakflate $18 \%$, hode $9 \%$ og genitalia $1 \%$ (fig 1). Denne tilnærmingen gjelder ikke for barn under 12 år, hvor hodet utgjør relativt mer av overflaten (tab 3$)(\underline{16})$. Håndflaten med samlede fingre utgjør ca. $1 \%$ av kroppsoverflaten. 


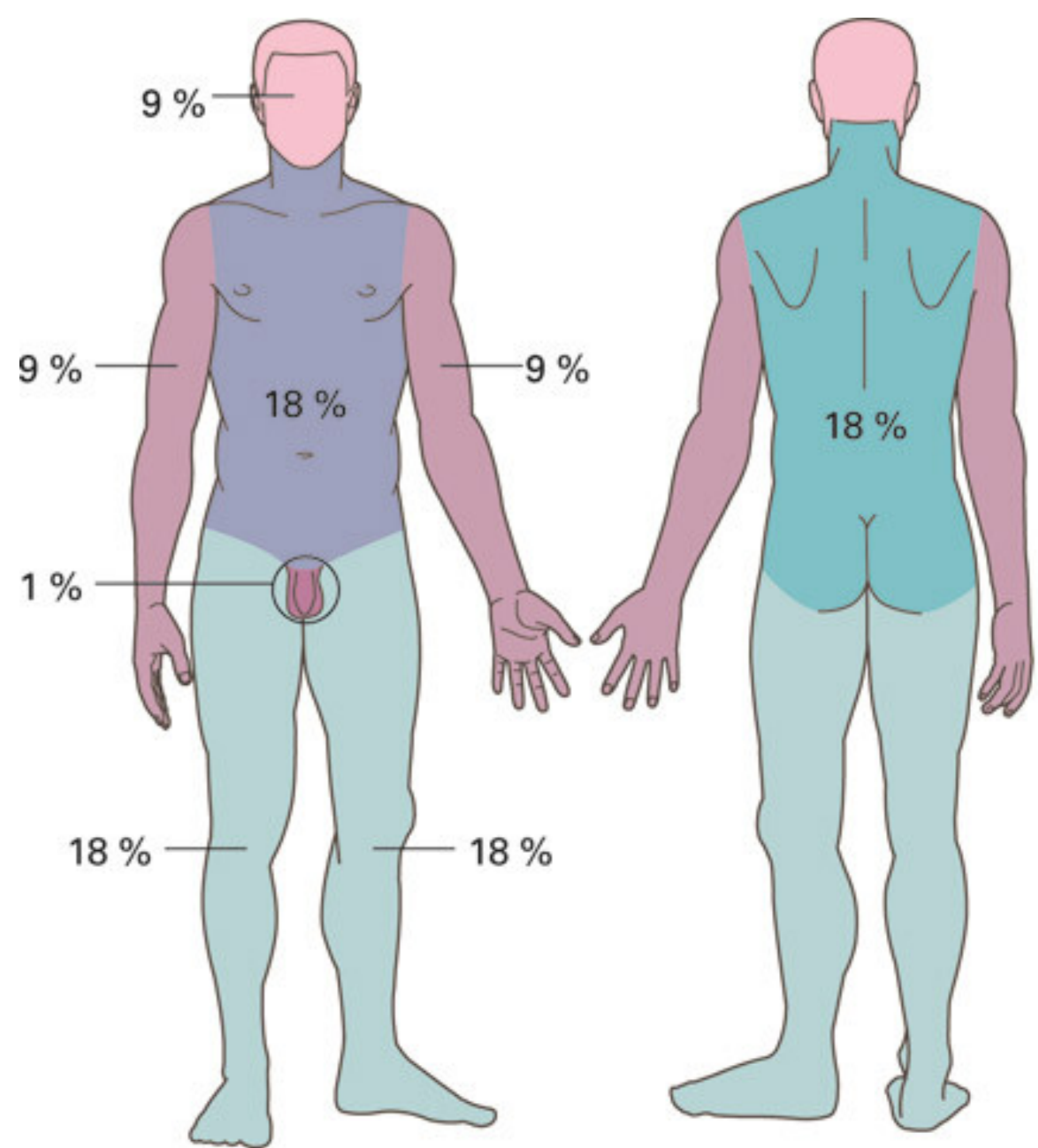

Figur 1 Klinisk vurdering av skadeutbredelse hos voksen pasient - «nierregelen»

\section{Tabell 3}

Skadeutbredelse, barn. Modifisert etter Lund \& Browder (16). Gjengitt med tillatelse fra J Am Coll Surg

\begin{tabular}{|lccccc|}
\hline Område/alder & $\mathbf{0 - 1} \mathbf{a} \mathbf{r}$ & $\mathbf{1 - 4} \mathbf{a} \mathbf{r}$ & $\mathbf{5 - 9} \mathbf{a} \mathbf{r}$ & $\mathbf{1 0 - 1 4} \mathbf{a} \mathbf{r}$ & $\mathbf{1 5} \mathbf{a} \mathbf{r}$ \\
\hline Hode & 19,0 & 17,0 & 13,0 & 11,0 & 9,0 \\
\hline Nakke & 2,0 & 2,0 & 2,0 & 2,0 & 2,0 \\
\hline Truncus foran & 13,0 & 13,0 & 13,0 & 13,0 & 13,0 \\
\hline Truncus bak & 13,0 & 13,0 & 13,0 & 13,0 & 13,0 \\
\hline Venstre nates & 2,5 & 2,5 & 2,5 & 2,5 & 2,5 \\
\hline Høyre nates & 2,5 & 2,5 & 2,5 & 2,5 & 2,5 \\
\hline Genitalia & 1,0 & 1,0 & 1,0 & 1,0 & 1,0 \\
\hline Høyre overarm & 4,0 & 4,0 & 4,0 & 4,0 & 4,0 \\
\hline Venstre overarm & 4,0 & 4,0 & 4,0 & 4,0 & 4,0 \\
\hline Høyre underarm & 3,0 & 3,0 & 3,0 & 3,0 & 3,0 \\
\hline Venstre underarm & 3,0 & 3,0 & 3,0 & 3,0 & 3,0 \\
\hline Høyre hånd & 2,5 & 2,5 & 2,5 & 2,5 & 2,5 \\
\hline Venstre hånd & 2,5 & 2,5 & 2,5 & 2,5 & 2,5 \\
\hline
\end{tabular}




\begin{tabular}{|lccccc|}
\hline Område/alder & $\mathbf{0 - 1}$ år & $\mathbf{1 - 4} \mathbf{a} \mathbf{r}$ & $\mathbf{5 - 9}$ år & $\mathbf{1 0 - 1 4}$ år & $\mathbf{1 5}$ år \\
\hline Høyre lår & 5,5 & 6,5 & 8,0 & 8,5 & 9,0 \\
\hline Venstre lår & 5,5 & 6,5 & 8,0 & 8,5 & 9,0 \\
\hline Høyre legg & 5,0 & 5,0 & 5,5 & 6,0 & 6,5 \\
\hline Venstre legg & 5,0 & 5,0 & 5,5 & 6,0 & 6,5 \\
\hline Høyre fot & 3,5 & 3,5 & 3,5 & 3,5 & 3,5 \\
\hline Venstre fot & 3,5 & 3,5 & 3,5 & 3,5 & 3,5 \\
\hline Sum & 100,0 & 100,0 & 100,0 & 100,0 & 100,0 \\
\hline
\end{tabular}

\section{Primærvurdering}

Pasienter med utbredte brannskader er ofte våkne umiddelbart etter skaden. Påvirket bevissthet gir mistanke om andre skader og/eller sykdommer, rusmiddelbruk, CO-eller cyanidpåvirkning. Noen pasienter har vært utsatt for et traume med høy energi (f.eks. eksplosjon, fall, bilulykke) og skal initialt undersøkes av traumeteam som multitraumepasienter ved det sykehus som primært behandler pasienten.

\section{Primærbehandling}

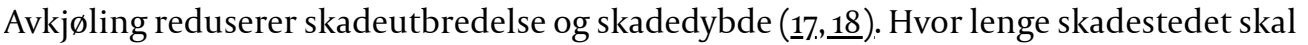
avkjøles og hvilken temperatur vannet skal ha er uavklart. Studier på rotter har vist at kjøling kan ha effekt selv om man starter så sent som inntil zo minutter etter påført skade, og at det er bedre effekt desto lenger skadestedet kjøles ned. Det er også vist at bruk av isvann skader vevet (19.). I én studie blir det anbefalt å skylle med vann som holder $12-18{ }^{\circ} \mathrm{C}$ i 20 minutter (19). Det anbefales å fortsette til smerten forsvinner. I forbindelse med kjøleprosedyren er det viktig å unngå at pasienten får lav kroppstemperatur.

Luftveishåndtering hos pasienter med brannskade i hode-hals-regionen er utfordrende pga. redusert gapeevne og ødemdanning i ansikt, munn og svelg. Tidlig orotrakeal intubasjon er ofte nødvendig for å sikre fri luftvei. På grunn av ødemutvikling må intubasjon skje med uklippet tube.

Ved skade på mer enn 10-15\% av kroppsoverflaten må væskebehandling i henhold til Parkland-formelen startes så snart som mulig (ramme 1) for å unngå nyresvikt som følge av alvorlig hypovolemi. Volumstatus vurderes fortløpende på bakgrunn av timediurese, pulsfrekvens og blodtrykk og senere også erytrocyttvolumfraksjon (EVF), baseoverskudd (BE) og serum-laktat.

\section{Ramme 1}

\section{Forventet vaeskebehov de første 24 t etter skaden, voksne}

Ringer-acetat: $4 \mathrm{ml} / \mathrm{kg} /$ prosentandel skadet areal (skadet areal: sum delhudsskade og fullhudsskade). Halvparten av væsken gis de første åtte timene etter skaden. Væsketilførselen justeres etter klinisk effekt

\section{Regneeksempel}

En pasient på $70 \mathrm{~kg}$ med en $50 \%$-skade 
Forventet væskebehov (Ringer-acetat, $4 \mathrm{ml} / \mathrm{kg} /$ prosentandel) de første 24 t etter skaden $4 \mathrm{ml} / \mathrm{kg} / \% \cdot 70 \mathrm{~kg} \cdot 50 \%=14000 \mathrm{ml}$

De første 7 ooo ml gis i løpet av de første åtte timene, det er da væskelekkasjen er størst

Forventet vaskebehov de første 24 t etter skaden, barn $<30 \mathrm{~kg}$

Basalt væskebehov dekkes med drikke og/eller glukose $50 \mathrm{mg} / \mathrm{ml}$ :

3-10 kg: $100 \mathrm{ml} / \mathrm{kg} / \mathrm{d} ø g \mathrm{n}$

10-20 kg: $1000 \mathrm{ml} / \mathrm{d} ø g \mathrm{n}+50 \mathrm{ml} / \mathrm{d} \emptyset \mathrm{gn}$ for hver kilo over $10 \mathrm{~kg}$

20-30 kg: $1500 \mathrm{ml} / \mathrm{d} \emptyset \mathrm{gn}+20 \mathrm{ml} / \mathrm{d} \emptyset g n$ for hver kilo over $20 \mathrm{~kg}$

Ekstra væskebehov pga. brannskaden dekkes med Ringer-acetat: $3 \mathrm{ml} / \mathrm{kg} / \%$ skadet areal

\section{Regneeksempel}

Barn $12 \mathrm{~kg}, 30$ \% skade

Basalbehov (glukose $50 \mathrm{mg} / \mathrm{ml}$ ): $1000 \mathrm{ml}+50 \mathrm{ml} \cdot 2=1100 \mathrm{ml}$

Tillegg for skade (Ringer-acetat): $3 \mathrm{ml} / \mathrm{kg} / \% \cdot 12 \mathrm{~kg} \cdot 30 \%=108 \mathrm{o} \mathrm{ml} / 24 \mathrm{t}$

Sum $=2180 \mathrm{ml}$

Ved sirkulære dype brannskader på ekstremitetene kan kombinasjonen av ødem og nedsatt elastisitet i brent hud føre til avklemming av kar og nerver og dermed true den perifere sirkulasjonen og skade sensibilitet og/eller motorikk. I slike situasjoner skal

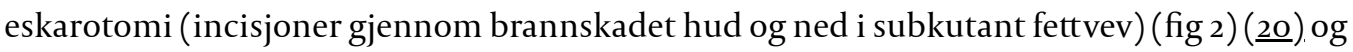
fasciotomi vurderes og eventuelt initieres så raskt som råd er av kompetent kirurg. Utbredte dype skader på truncus kan også hindre ekspansjon av thorax med påfølgende nedsatt pusteevne og venøs retur til hjertet. I slike tilfeller skal eskarotomi utføres ved sykehuset der primærbehandlingen finner sted (fig 2). 

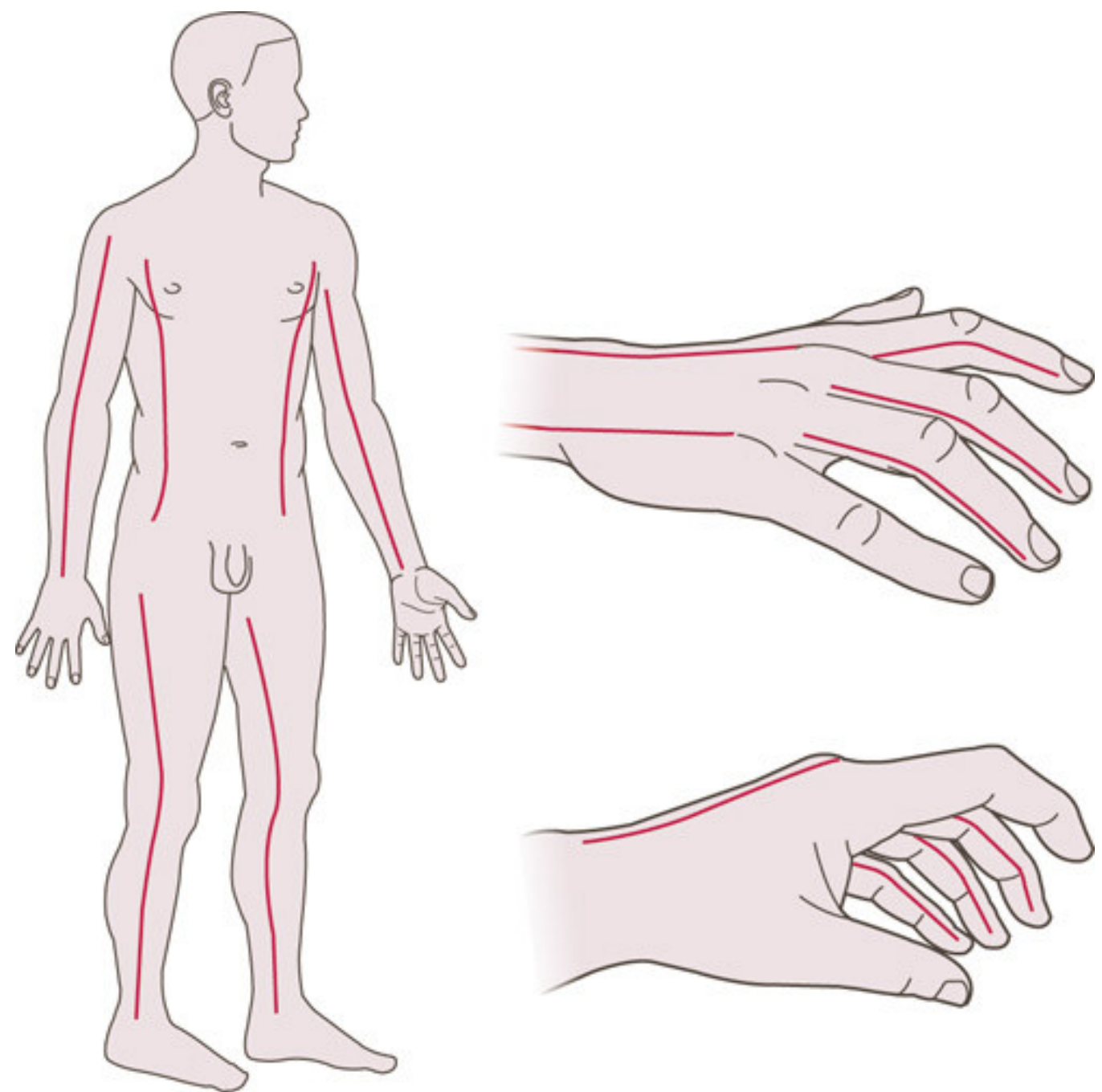

Figur 2 Akuttkirurgi - eskarotomi. Røde linjer indikerer anbefalt snittføring ved eskarotomi. Ved behov eskarotomeres tommel på radialsiden og pekefing på ulnarsiden. Ikke eskarotomi i pinsettgrepet, på femte fingers ulnarside eller dorsalt eller volart på fingrene. Gjengitt med tillatelse fra NAForum (20)

\section{Væskebehandling de første 24 timer}

Målet for væskebehandlingen er å sikre tilstrekkelig blodtilførsel til alle vitale organer med så lite tilført væske som mulig. De første 12-24 timer etter skaden gis en balansert elektrolyttløsning, f.eks. Ringer-acetat. Det bør tilstrebes en timediurese på o,5 ml/kg/t hos

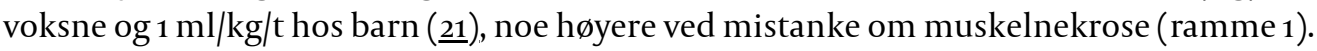

Lekkasjen av proteinmolekyler er redusert etter 12-30 timer (므), man regner derfor med at kolloider tilført senere enn 24 timer etter skaden retineres bedre i blodbanen. Dersom kolloider gis tidligere, vil en større del lekke gjennom kapillarmembranen til interstitiet. Hos pasienter med stort væskebehov kan kolloider være nødvendig allerede 8-12 timer etter skadetidspunktet (7.). Parkland-formelen (ramme 1) gir et estimat for væskebehovet, men væsketilførselen må alltid justeres etter klinisk respons for å unngå hypovolemi og for å begrense unødig overhydrering og ødemdanning. I denne fasen skyldes manglende diurese ved åpent urinkateter vanligvis hypovolemi. Diuretika bør unngås i resusciteringsfasen fordi det ødelegger muligheten til å bruke timediurese som klinisk respons på væsketilførselen. Klinisk erfaring viser at væskebehovet de første 24 timene etter skaden ofte er økt hos brannskadede med samtidig inhalasjonsskade.

\section{Væskebehandling etter 24-48 timer}


Etter 24 timer er kapillarlekkasjen vanligvis mindre. Ringer-acetat bør da seponeres og det bør startes med kolloider. Et utgangspunkt for kolloidtilførselen kan være o,5 $\mathrm{ml} / \mathrm{kg} /$ prosentandel skadet areal over en åttetimersperiode, men ofte vil det være nødvendig å gi større volum. I tillegg gis glukose $50 \mathrm{mg} / \mathrm{ml}$ intravenøst, sondemat og ev. drikke som bidrar til ønsket diurese på o,5-1 ml $/ \mathrm{kg} / \mathrm{t}$. Målet er at væskebehandlingen fra og med 48 timer etter skaden skal gi negativ vann-og-salt-balanse samtidig som det sirkulerende blodvolumet bibeholdes. I denne fasen er moderat hyponatriemi (130 $\mathrm{mmol} / \mathrm{l}$ ) vanlig. Tilførsel av ekstra natrium er vanligvis ikke indisert i denne fasen, på grunn av et absolutt natriumoverskudd etter stor tilførsel av natrium de første 24 timene etter skaden.

\section{Væskebehandling etter 48 timer (avvanningsfasen)}

Så lenge pasienten har sårflater som ikke er tilhelet, vil væskebehovet være økt på grunn av siving og fordamping. Sammen med fritt vann vil det også tapes proteinholdig væske, og etter hvert vil det være behov for ekstra tilførsel av vann og natrium samt ekstra kolloider.

\section{Tilganger}

Ved større brannskader bruker vi intraarteriell blodtrykksmåling. Bruk av mangelumen sentralvenøse katetre er en forutsetning for kontinuerlig og pålitelig tilførsel av vasoaktive medikamenter i kombinasjon med sedativer, blod- og blodprodukter, kolloider, væske og parenteral ernæring. Vi tilstreber innlegging av arterie- og venekatetre gjennom områder med uskadet hud. Regelmessig skifting av alle invasive katetre og bruk av sentrale

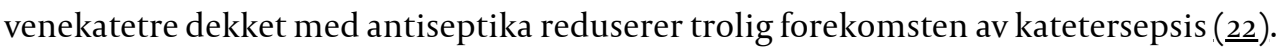

Bruk av blærekateter med temperaturmål er nyttig for å følge pasientens kjernetemperatur og for å monitorere væskebehandlingen. En myk ernæringssonde bør legges til ventrikkelen for oppstart av enteral ernæring.

\section{Overflytting og transport}

Pasienten stabiliseres på skadestedet og overflyttes med ambulanse eller helikopter til nærmeste sykehus med kirurgisk kompetanse i brannskadebehandling. Her bør det gjennomføres en ny vurdering av skadeomfanget.

Digitale bilder bør gjøres tilgjengelig for vurdering av skaden sammen med vakthavende plastikkirurg og anestesiolog ved Brannskadeavsnittet. Bildene kan også avdekke et ev. behov for akutt kirurgisk intervensjon, og man kan bedre vurdere om det er indikasjon for å transportere pasienten videre til et sykehus med høyere kompetanse på behandling av brannskader (ramme 2).

\section{Ramme 2}

\section{Kriterier for vurdering av overflytting til Brannskadeavsnittet, Haukeland universitetssykehus}

- Barn med $>5 \%$ dyp delhuds- og/eller fullhudsskade

- Voksne med $>15 \%$ dyp delhuds- og/eller fullhudsskade

- Dypere og/eller sirkulære skader på hender/genitalia/ansikt

- Høyvoltskader

- Kjemiske skader

- Store hudsår av annen årsak 
Tidspunkt for eventuell overflytting avtales med det for øye at pasientens vitale organfunksjoner bør være mest mulig stabile, luftveiene må om nødvendig være sikret og pasienten må være bandasjert og innpakket på en slik måte at normal kroppstemperatur kan bibeholdes under transporten.

På grunn av store geografiske avstander har man her i landet tradisjonelt behandlet mange med moderate til utbredte brannskader ved lokale plastikkirurgiske og ortopediske avdelinger (tab 1).

\section{Kirurgisk behandling}

Ved brannskader etter alvorlige ulykker og der det er tvil om skademekanismen skal de rammede behandles som traumepasienter. De kirurgiske tiltakene i mottakssituasjonen er beskrevet under primærbehandling. Overflatiske delhudsskader behandles konservativt med sårskift til de er helet. Dype delhudsskader behandles vanligvis operativt, og store områder med fullhudsskade må alltid opereres. De fleste brannskadeavdelinger i den vestlige verden praktiserer tidlig nedskjæring, da dette har vist seg å gi høyere overlevelse (23). Nedskjæring og høsting av hud til transplantasjon kan gi betydelig blødning. Tidlig transfusjon, vektlegging av effektiv kirurgi, normotermi, god hemostase og aktivt samarbeid mellom anestesilege og kirurg er vesentlig. Ved utbredte skader vil pasienten vanligvis trenge flere operasjoner. Etter primæroppholdet kan det være behov for senere rekonstruktive inngrep for å optimalisere funksjon og kosmetisk resultat.

\section{Sårstell}

Pasienter med store brannskader gjennomgår ofte daglig omfattende og tidkrevende sårstell. På transplanterte områder fjernes bandasjene 3-5 dager etter transplantasjonen, med mindre siving av sårvæske og mistanke om infeksjon tilsier tidligere inspeksjon av det skadede området. Stell av brannsår er smertefullt, og det er ofte nødvendig med generell anestesi. Når forholdene er lagt til rette for det, kan sårstellene som regel gjennomføres på pasientens rom (eller behandlingsrom), uten bruk av ressursene på operasjonsavdelingen.

\section{Smertelindring}

Ved større brannskader vil pasientene ofte ha behov for fast opiattilførsel - med tilskudd av ekstradoser ikke bare før sårstell, men også før fysioterapi og mobilisering (24). Opiatbehovet varierer. Ved en behandling som ofte strekker seg over mange uker, ses toleranseutvikling for opiater. Sammen med opiater, og som basismedikasjon, brukes paracetamol eller ikke-steroide antiinflammatoriske midler (25). Pasientkontrollert analgesi brukes i liten grad hos oss for prosedyrerelatert smerte. Når sårene etter hvert er under tilheling, kan opiatdosen vanligvis over noe tid reduseres og etter hvert seponeres uten vesentlige problemer. Etter utskrivning har mange pasienter fortsatt store plager med kløe (므) og dysestesi (27.) i skadede områder.

\section{Respirasjonssvikt}

Tradisjonelt har man ved brannskade i ansikt og på hals vært tilbakeholden med tidlig trakeostomi pga. faren for at ødem skal dislokere trakealkanylen. Ved dyp skade på halsen utsettes ved behov for langvarig respiratorbehandling trakeostomi til eventuelle transplantater på halsen er tilhelet. Respirasjonssvikt er primært betinget i inhalasjon av toksiske produkter, senere sekretretensjon, atelektase, pneumoni, overvæsking og som ledd i sepsis. Gjentatte bronkoskopier kan være nødvendig for å fjerne seigt sekret fra 
luftveiene, og nøyaktig bronkialtoalett er nødvendig for å forhindre tubeokklusjon. Tidlig ekstubasjon er et mål, selv hos pasienter der skadeomfanget er stort. Erfaring viser at hyppige sårstell ofte kan gjennomføres i generell anestesi uten intubasjon, men med spontanventilasjon på maske med kontinuerlig overtrykk.

\section{Hjertesvikt}

I akuttfasen (o-24 t) skyldes hypotensjon vanligvis hypovolemi. Myokarddepresjon er én mulig følge av større brannskader og har vært tilskrevet en sirkulerende myokarddeprimerende faktor ( $\underline{28})$. Hvis pasienten er ustabil og har et uventet høyt væskebehov, kan det være nødvendig med forsterket hemodynamisk overvåking ved hjelp av PiCCO- eller pulmonalarteriekateter, som kan gi en pekepinn om hvorvidt mer væske eller vasoaktive medikamenter (dobutamin og noradrenalin) er nødvendig(29).

Senere i forløpet kan systemisk inflammatorisk respons-syndrom (SIRS) gi vasodilatasjon og hypotensjon ledsaget av høyt hjerteminuttvolum. I denne fasen kan infusjon av vasopressor, fortrinnsvis noradrenalin, være hensiktsmessig for å opprettholde et middelarterietrykk tilstrekkelig til å oppnå diurese og bevare nyrefunksjonen. Behandlingen må også rettes mot infeksjonssanering og å begrense feberreaksjonen. Romtemperaturen må være høy nok til at termogenese ved muskelskjelving unngås.

\section{Infeksjon}

Infeksjon er den vanligste komplikasjonen ved både små og store brannskader (30). På tross av dette bruker vi ikke profylaktisk systemisk antibiotika, blant annet for å hindre seleksjon av multiresistente mikrober og soppinfeksjon. For å begrense faren for kryssinfeksjon mellom pasientene er enerom med kontaktsmitteregime å foretrekke.

Sårområder koloniseres ofte. I penselprøver fra sår finnes hyppig vekst både av normal hudflora og av patogene mikrober (stafylokokker, streptokokker, enterokokker og/eller ulike gramnegative staver). Det er vanskelig å vurdere tidspunkt for oppstart av antibiotikabehandling, vekst i penselprøver fra hud alene er vanligvis ikke grunnlag for å starte behandling med systemiske antibiotika. Selv ved fravær av invasiv infeksjon er CRPnivået oftest tresifret og temperaturen regelmessig $>38^{\circ} \mathrm{C}$ pga. systemisk inflammatorisk respons-syndrom. Etter sårstellet har mange pasienter temperaturstigning og i noen tilfeller frostanfall. Inntil 50 \% av dem med større brannskader kan ha forbigående bakteriemi etter sårstell (31).

Markert stigende CRP-nivå, fallende trombocyttall, feber $>39^{\circ} \mathrm{C}$, lukt fra sårene, $\varnothing$ kende ventrikkelretensjon, stigende blodsukkernivå og/eller pneumonisuspekte lungefortetninger gir mistanke om systemisk infeksjon og kan styrke indikasjonen for oppstart av systemisk antibiotikabehandling. Før oppstart må det alltid tas bakteriologiske prøver fra blod, sårområder, nedre luftveier og urin. Blodkulturer tas før sårstell, fra nytt innstikk, etter at huden er desinfisert.

\section{Nyresvikt}

Tidlig nyresvikt skyldes ofte forsinket eller for liten væsketilførsel, men kan også ses ved kronisk hypertensjon, hemolyse eller omfattende muskelnekrose. Nyresvikt kan også utvikles som ledd i abdominalt kompartmentsyndrom (32) som følge av svær væsketilførsel i den initiale fasen av behandlingen. Sen nyresvikt er vanligvis en følge av sepsis, som ledd i annen organsvikt. Nyresvikt kan også opptre som komplikasjon til bruk av nefrotoksiske medikamenter. 
Lav diurese på tross av adekvat væsketilførsel er ofte det første tegn på akutt nyresvikt, etterfulgt av $ø$ kende serum-karbamid og -kreatinin. Tidlig start av nyreerstattende behandling (hemodialyse eller venovenøs hemofiltrasjon) vil kunne korrigere metabolske forstyrrelser og tillate en aktiv holdning til ernæring og trekking av et eventuelt væskeoverskudd.

\section{Sentralnervøs svikt}

Brannskader kan være forbundet med hypoksisk hjerneskade. Stor væsketilførsel er ofte nødvendig på grunn av brannskaden, noe som kan bidra til å forverre et hjerneødem og dermed øke det intrakraniale trykket (33). Måling av intrakranialt trykk kan være aktuelt i et forsøk på å balansere væskebehandlingen mot en tendens til utvikling av hjerneødem (34).

\section{Ernæring og manipulering av stressresponsen}

Sykdom gir dårlig appetitt og vekttap. Hos intensivpasienter er vekttapet ofte stort i forbindelse med intensivoppholdet (35). Ved store brannskader er basalmetabolismen $\emptyset \mathrm{kt}$. Pasientene er katabole og kan raskt få en betydelig muskelatrofi. Når allmenntilstanden etter hvert bedres og væskeoverskuddet mobiliseres, kommer vekttapet til syne.

Serum-glukosenivået er ofte høyt, også hos ikke-diabetikere. I en rekke studier har man forsøkt å manipulere stressresponsen i den hensikt å redusere katabolismen og dermed bedre utfallet for pasienten ( $\underline{8}$ ). Den hypermetabole responsen etter brannskade kan ikke elimineres fullstendig, men kan dempes av tidlig nedskjæring og transplantasjon, høy temperatur i pasientrommet, god smertebehandling, effektiv infeksjonskontroll og styrket og tilpasset ernæring. Stressresponsen kan også manipuleres ved bruk av lave doser insulin, oksandrolon (en syntetisk testosteronanalog) og betablokade (propranolol) (3므)(3ㅇ). Disse tiltakene reduserer tapet av fettfri kroppsmasse og har også bedret lengdeveksten etter brannskade hos barn (3므).

Energibehovet er økt hos brannskadepasienter. Den beste måten å fastsette det på er å gjøre indirekte kalorimetri, en metode som ikke er i utbredt bruk. De mange formler som finnes for utregning av energibehovet er unøyaktige og overestimerer (39.). I de nye retningslinjene fra The European Society for Clinical Nutrition and Metabolism (ESPEN) anbefales det at brannskadepasienter får ekstra tilskudd av glutamin enteralt og/eller parenteralt (4으,41), og i en studie er det vist at enteralt tilført glutamin bedret sårtilhelingen og reduserte liggetiden (42). Det er også data som tyder på at brannskadepasienter har behov for økt tilskudd av sink, selen og kobber (43).

For å bedømme væskebalansen er daglig veiing nødvendig i initialfasen. Senere i forløpet kan veiing tre ganger i uken samt måling av natrium, kalium og karbamid i døgnurin lette bedømmelsen av endring i væskebalansen og/eller ernæringsstatus.

Brannskadepasienter er utsatt for å få stressmagesår. I akuttfasen, før man har kommet opp i full mengde enteral ernæring, bør pasienten få profylakse mot magesår.

\section{Konklusjon}

Pasienter med store brannskader bør behandles i en kirurgisk avdeling med spesialkompetanse på brannskadebehandling. Det er viktig å komme tidlig i gang med væskebehandling for å hindre organsvikt og senere sørge for at pasienten kvitter seg med overskuddsvæske i løpet av den første uken etter skaden. Primære kirurgiske tiltak, eskarotomi og/eller fasciotomier, må om nødvendig gjøres på primærsykehuset. 
Intensivbehandling hos denne pasientgruppen gjennomføres etter de samme prinsipper som hos andre kritisk syke. Definitiv kirurgisk behandling med eksisjon og transplantasjon bør starte tidlig for å redusere sannsynligheten for sepsis og organsvikt.

\section{Oppgitte interessekonflikter:}

Ingen

\section{Tabell}

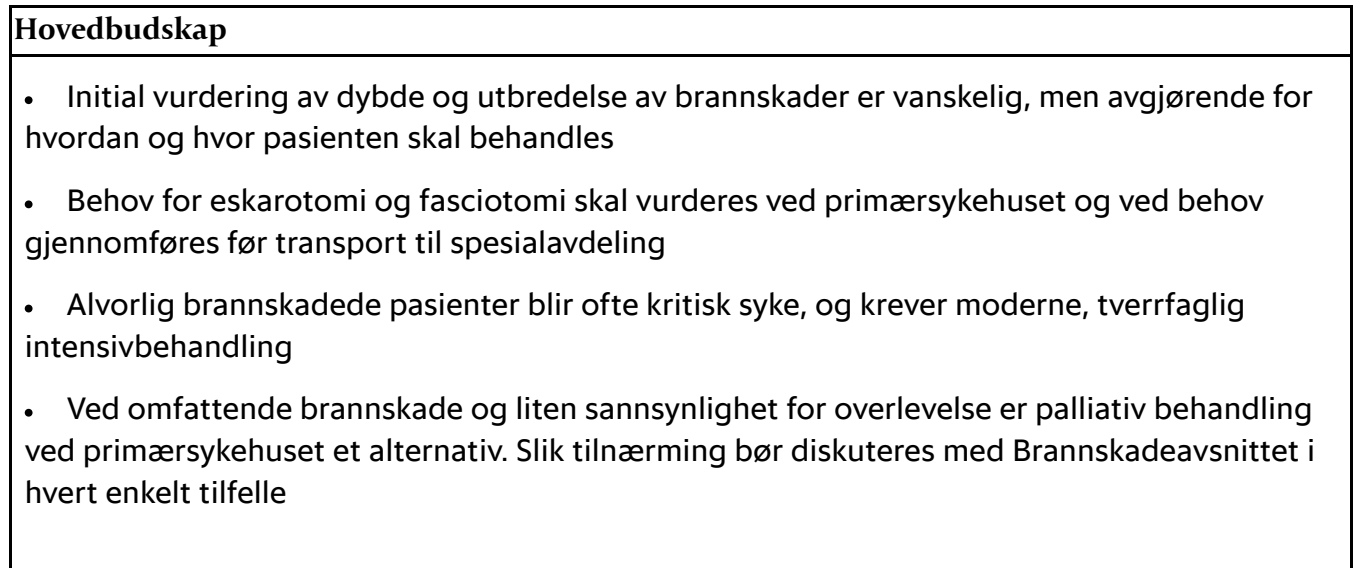

\section{LITTERATUR}

1. Onarheim H, Vindenes HA. Sykehusopphold for brannskade. Tidsskr Nor Lægeforen 2004; 124: 21302. [PubMed]

2. Onarheim H, Jensen SA, Rosenberg BE et al. The epidemiology of patients with burn injuries admitted to Norwegian hospitals in 2007. Burns 2009; 35: 1142-6. [PubMed] [CrossRef]

3. Metodebok Brannskadeavsnittet. Bergen: Brannskadeavsnittet, Plastikk kirurgisk avdeling, Haukeland universitetssykehus, 2007.

4. Lund T, Wiig H, Reed RK. Acute postburn edema: role of strongly negative interstitial fluid pressure. Am J Physiol 1988; 255: H1069-74. [PubMed]

5. Aanderud L, Lund T. Intensivbehandling av brannskader. Tidsskr Nor Lægeforen 1989; 109:3197-9. [PubMed]

6. Pitkänen J, Lund T, Aanderud L et al. Transcapillary colloid osmotic pressures in injured and noninjured skin of seriously burned patients. Burns Incl Therm Inj 1987; 13: 198-203. [PubMed] [CrossRef]

7. Lund T, Onarheim H, Reed RK. Pathogenesis of edema formation in burn injuries. World J Surg 1992; 16: 2-9. [PubMed] [CrossRef]

8. Jeschke MG, Chinkes DL, Finnerty CC et al. Pathophysiologic response to severe burn injury. Ann Surg 2008; 248:387-401. [PubMed]

9. Kealey GP. Carbon monoxide toxicity. J Burn Care Res 20o9;30:146-7. [PubMed] [CrossRef]

10. Weaver LK. Clinical practice. Carbon monoxide poisoning. N Engl J Med 2009;360: 1217-25. [PubMed] [CrossRef]

11. Juurlink DN, Buckley N, Stanbrook MB et al. Hyperbaric oxygen for carbon monoxide poisoning. Cochrane Database of Systematic Reviews 2005; Art No: CDoo2041. DOI:

10.1002/14651858.CDoo2041.pub2. [PubMed] 
12. Weaver LK, Hopkins RO, Chan KJ et al. Hyperbaric oxygen for acute carbon monoxide poisoning. N Engl J Med 2002; 347: 1057-67. [PubMed] [CrossRef]

13. Cescon DW, Juurlink DN. Discoloration of skin and urine after treatment with hydroxocobalamin for cyanide poisoning. CMAJ 2009; 180: 251. [PubMed] [CrossRef]

14. Barillo DJ. Diagnosis and treatment of cyanide toxicity. J Burn Care Res 2009;30: 148-52. [PubMed] [CrossRef]

15. Spies C, Trohman RG. Narrative review: electrocution and life-threatening electrical injuries. Ann Intern Med 2006; 145: 531-7. [PubMed]

16. Lund C, Browder N. The estimate of areas of burns. Surg Gynecol Obstet 1944; 79:352.

17. Nguyen NL, Gun RT, Sparnon AL et al. The importance of immediate cooling - a case series of childhood burns in Vietnam. Burns 2002; 28: 173-6. [PubMed] [CrossRef]

18. Jandera V, Hudson DA, de Wet PM et al. Cooling the burn wound: evaluation of different modalites. Burns 2000; 26: 265-70. [PubMed] [CrossRef]

19. Venter TH, Karpelowsky JS, Rode H. Cooling of the burn wound: the ideal temperature of the coolant. Burns 2007; 33: 917-22. [PubMed] [CrossRef]

20. Akuttkirurgi - eskarotomi. NAForum 2008; nr. 2: 43.

21. Herndon DN. Total burn care. 3. utg. Amsterdam: Elsevier, 2007.

22. Niel-Weise BS, Stijnen T, van den Broek PJ. Anti-infective-treated central venous catheters for total parenteral nutrition or chemotherapy: a systematic review. J Hosp Infect 2008; 69: 114-23. [PubMed] [CrossRef]

23. Ong YS, Samuel M, Song C. Meta-analysis of early excision of burns. Burns 2006; 32: 145-50. [PubMed] [CrossRef]

24. Summer GJ, Puntillo KA, Miaskowski C et al. Burn injury pain: the continuing challenge. J Pain 2007; 8: 533-48. [PubMed] [CrossRef]

25. Patterson DR, Hofland HW, Espey K et al. Pain management. Burns 2004; 30: A10-5. [PubMed] [CrossRef]

26. Goutos I, Dziewulski P, Richardson PM. Pruritus in burns: review article. J Burn Care Res 2009; 30: 221-8. [PubMed] [CrossRef]

27. Malenfant A, Forget R, Papillon J et al. Prevalence and characteristics of chronic sensory problems in burn patients. Pain 1996; 67: 493-500. [PubMed] [CrossRef]

28. Baxter CR, Cook WA, Shires GT. Serum myocardial depressant factor of burn shock. Surg Forum 1966; 17: 1-2. [PubMed]

29. Sjöberg F. The «Parkland protocol» for early fluid resuscitation of burns: too little, too much, or ... even ... too late ...? Acta Anaesthesiol Scand 2008; 52: 725-6. [PubMed]

30. Ansermino M, Hemsley C. Intensive care management and control of infection. BMJ 2004;329: 220-3. [PubMed] [CrossRef]

31. Vindenes $\mathrm{H}$, Bjerknes R. The frequency of bacteremia and fungemia following wound cleaning and excision in patients with large burns. J Trauma 1993; 35: 742-9. [PubMed] [CrossRef]

32. Azzopardi EA, McWilliams B, Iyer S et al. Fluid resuscitation in adults with severe burns at risk of secondary abdominal compartment syndrome - an evidence based systematic review. Burns 2009; 35: 911-20. [PubMed] [CrossRef]

33. Shin C, Kinsky MP, Thomas JA et al. Effect of cutaneous burn injury and resuscitation on the cerebral circulation in an ovine model. Burns 1998; 24:39-45. [PubMed] [CrossRef]

34. Kay S, Rao GS, Lord D et al. Intracranial pressure monitoring as an aid to resuscitation in the burnt and asphyxiated child: three case reports. Burns Incl Therm Inj 1986; 12: 212-3. [PubMed] [CrossRef]

35. Kvåle R, Ulvik A, Flaatten H. Follow-up after intensive care: a single center study. Intensive Care Med 2003; 29: 2149-56. [PubMed] [CrossRef]

36. Pereira CT, Herndon DN. The pharmacologic modulation of the hypermetabolic response to burns. Adv Surg 2005; 39: 245-61. [PubMed] [CrossRef]

37. Pereira C, Murphy K, Jeschke M et al. Post burn muscle wasting and the effects of treatments. Int J Biochem Cell Biol 2005; 37: 1948-61. [PubMed] [CrossRef]

38. Pereira CT, Murphy KD, Herndon DN. Altering metabolism. J Burn Care Rehabil 2005; 26: 194-9. [PubMed] 
39. Chan MM, Chan GM. Nutritional therapy for burns in children and adults. Nutrition 2009; 25: 261-9. [PubMed] [CrossRef]

40. Kreymann KG, Berger MM, Deutz NE et al. ESPEN Guidelines on enteral nutrition: intensive care. Clin Nutr 2006; 25: 210-23. [PubMed] [CrossRef]

41. Singer P, Berger MM, Van den Berghe G et al. ESPEN Guidelines on parenteral nutrition: intensive care. Clin Nutr 2009; 28:387-400. [PubMed] [CrossRef]

42. Peng X, Yan H, You Z et al. Clinical and protein metabolic efficacy of glutamine granulessupplemented enteral nutrition in severely burned patients. Burns 2005;31:342-6. [PubMed] [CrossRef]

43. Berger MM, Shenkin A. Trace element requirements in critically ill burned patients. JTrace Elem Med Biol 2007; 21 (suppl 1): 44-8. [PubMed] [CrossRef]

Publisert: 17. juni 2010. Tidsskr Nor Legeforen. DOI: 10.4045/tidsskr.08.0391

Manuskriptet ble mottatt 17.10. 2008 og godkjent 8.4. 2010. Medisinsk redaktør Are Brean.

(C) Tidsskrift for Den norske legeforening 2023. Lastet ned fra tidsskriftet.no 26. april 2023. 